3) Residual soil is pronounced on norite rocks and has weakly developed soil profiles.

4) Soil development is dependent on drainage, vegetation cover and relative age of the parent material.

5) The A horizon is the most common soil horizon observed.

Conclusions regarding the trace element content and distribution of the soil samples, as well as the applicability of the method, will be presented after completion of the analytical programme.

\title{
References
}

Holowaychuk, J. N. \& Everett, K. R. 1972: Soils of the Tasersiaq area, Greenland. Meddr Grønland 188(6), $37 \mathrm{pp}$.

Kunzendorf, H. \& Sørensen, P. 1982: Reconnaisance geochemical sampling in the Qaqarssuk Carbonatite Complex, West Greenland. Unpubl. intern. Risø report. $10 \mathrm{pp}$.

Tedrow, J. C. F. 1970: Soil investigations in Inglefield land, Greenland. Meddr Grønland 188(3), 32-93.

Ugolini, F. C. 1966: Soils of the Mesters Vig district, Northeast Greenland. Meddr Grønland 176(1), 23 pp.

Institut for almen Ger $\emptyset$ ster Voldgade 10 $D K-1350$ Copenhagen $K$.

\section{A magnetic and electromagnetic investigation of disseminated sulphide mineralisation at 'Fossilik', central West Greenland}

\section{Leif Thorning}

In summer 1982 an experimental geophysical investigation was carried out for one month around an occurrence of disseminated iron-copper sulphides at 'Fossilik', Sukkertoppen. A geochemical sampling programme was undertaken by other geologists.

The object of the geophysical work was to investigate various geophysical methods and instruments in relation to iron-copper sulphide mineralisation in a norite body. For this purpose the Apex Maxmin II and the Geonics EM16/16R were hired from Fenning Environmental Services.

The geophysical activities involved were: (1) magnetic profiling with a Geometrics G856 proton magnetometer; (2) very low frequency (VLF) electromagnetic (EM) measurements using the Geonics EM16 and the American VLF station NAA, $17.8 \mathrm{kHz}$; (3) VLF resistivity measurements using the Geonics EM16R and the same VLF station; (4) horizontal loop EM measurements using the Apex Maxmin II at frequencies $222 \mathrm{~Hz}, 444 \mathrm{~Hz}, 888 \mathrm{~Hz}, 1777 \mathrm{~Hz}$ 
and $3555 \mathrm{~Hz}$ and transmitter receiver distances of 25,50 and $100 \mathrm{~m}$; and (5) susceptibility measurements using the Scintrex SM5 susceptibility meter.

The profile lines were laid out with a theodolite to obtain very accurate chaining data for the topographic correction of the horizontal loop EM measurements. The total length of these profile lines was approximately $4 \mathrm{~km}$. Geophysical data were collected along practically all lines. An additional 1 to $2 \mathrm{~km}$ of magnetic and VLF data were acquired along reconnaissance profiles in the area.

The data were compiled in the field (diurnal correction of magnetic data, filtering of VLF data, Fraser, 1969). The horizontal loop EM measurements did not add to the results obtained with the VLF profiling, except to indicate that no massive sulphides were present at low to moderate depths. Consequently, the combination of VLF, EM and magnetics can be recommended for the mapping of these norite/sulphide occurrences with associated faulting. The multifrequency horizontal loop EM cannot be recommended for mapping work, but may of course still be valuable for detailed work on more massive sulphides of which there are some in the area (Secher this report).

Good results were obtained and it was possible to interpret the data in relation to the geologic features. Data and results will be presented later.

Acknowledgement. Egon Hansen and Ingrid Salinas assisted with the investigation. Logistic support was given by the geological mapping team based at Kangiussaq.

\section{Reference}

Fraser, D. C. 1969: Contouring of VLF-EM data. Geophysics, 34, 958-967.

\section{Anatectic origin of mid-Proterozoic granite dyke in the Isukasia area, West Greenland $\mathrm{Pb}-\mathrm{Pb}$ and $\mathrm{Rb}-\mathrm{Sr}$ isotope evidence}

\section{F. Kalsbeek and P. N. Taylor}

It was found some time ago on the evidence of mineral-isotope relations that the early Archaean gneisses of the Godthåbsfjord region in West Greenland were mildly reheated during the mid-Proterozoic at c. 1600-1700 Ma (Pankhurst et al., 1973; Baadsgaard et al., 1976). A Rb-Sr whole-rock isotope study of a fine-grained granitic dyke from the Isukasia area indicated that this dyke was formed $1610 \pm 130 \mathrm{Ma}$ ago by anatexis of early Archaean rocks (Kalsbeek et al., 1980). This suggested that temperatures not less than $c .650^{\circ} \mathrm{C}$ were reached at depth, at least locally, within the Archaean craton during the Proterozoic. We have made a $\mathrm{Pb}-\mathrm{Pb}$ isotope study of this dyke to check and amplify this conclusion. The field relations, petrology and chemistry of the dyke have been described in the earlier paper. 